\title{
Flame Atomic Absorption Spectrometric Determination of Trace Amounts of Zinc and Thallium in Different Matrixes after Solid Phase Extraction on Modified Multiwalled Carbon Nanotubes
}

\author{
Sayed Zia Mohammadi \\ Department of Chemistry, Payame Noor University, P.O. Box 19395-4697, Tehran, Iran \\ Email: szmohammadi@yahoo.com
}

Received February 25, 2012; revised March 13, 2012; accepted March 30, 2012

\begin{abstract}
The potential of modified multiwallcd carbon nanotubes, as a solid-phase extraction sorbent for the simultaneous separation and preconcentration of zinc and thallium has been investigated. Zinc and thallium were adsorbed quantitatively onto modified multiwalled carbon nanotubes in the $\mathrm{pH}$ range of $3-6.5$. Parameters influencing the simultaneous preconcentration of $\mathrm{Zn}(\mathrm{II})$ and $\mathrm{Tl}(\mathrm{I})$ ions such as $\mathrm{pH}$ of the sample, sample and eluent flow rate, type and volume of elution solution and interfering ions, have been examined and optimized. Linearity was maintained between 0.1 to 20.0 $\mu \mathrm{g} \cdot \mathrm{mL}^{-1}$ for thallium and $20.0 \mathrm{ng} \cdot \mathrm{mL}^{-1}$ to $5.0 \mu \mathrm{g} \cdot \mathrm{mL}^{-1}$ for zinc in the final solution. The defection limits based on three times the standard deviation of the blank signal $(\mathrm{n}=8)$ for thallium and zinc were 5.1 and $1.4 \mathrm{ng} \cdot \mathrm{mL}^{-1}$, respectively. Seven replicate determination of a mixture of 5.0 and $0.2 \mu \mathrm{g} \cdot \mathrm{mL}^{-1}$ of thallium and zinc in the final solution gave a mean absorbance of 0.085 and 0.074 with relative standard deviation $1.5 \%$ and $1.7 \%$, respectively. The method has been applied for the determination of trace amounts of zinc and thallium in biological and water sample with satisfactory results.
\end{abstract}

Keywords: Carbon Nanotubes; Zinc Determination; Thallium Determination; Preconcentration

\section{Introduction}

The major increase in the use of toxic elements has resulted in high concentration of metals in aquatic systems. There are numerous sources of industrial effluents leading to heavy metal discharges apart from the mining and metal related industries [1-3]. Because of their toxicity and non biodegradable nature, metals are of special significance. The presence heavy metals in wastewater and surface water are becoming a severe environmental and public health problem.

Direct determination of metals in seawater samples by atomic absorption spectrometry, inductively coupled plasma optical emission spectrometry (ICP-OES) or inductively coupled plasma mass spectrometry (ICP-MS) is not always possible due to matrix interferences and the very low concentrations of metal ions [4].

Preconcentration is widely applied in a number method such as: flame atomic absorption spectrometry (FAAS), ICP-OES, electrothermal atomic absorption spectrometry (ETAAS) or ICP-MS. In the first case, preconcentration step improves detection limit and enables analyte determination at trace concentrations [5]. The remaining me- thods are good analytical tools for trace analyses; nevertheless they are not free from influence of a complicated sample matrix. Therefore, apart from preconcentration, separation of an analyte from the matrix is frequently needed as it reduces interference effect by simplifying the sample matrix [6-9].

The most widely used techniques for the separation and preconcentration of trace metals include solid phase extraction, coprecipitation, liquid-liquid extraction, membrane filtration, floatation and cloud point extraction [10-18]. Among preconcentration methods, SPE has some advantages such as ease regeneration of solid phase, high preconcentration factor, and reusability of the adsorbent, low consumption of reagents, ease of automation, ecofriend methods and ease usage [19]. It is noticeable that SPE not only separates and concentrates samples but also performs as cleaner samples.

Since its discovery in 1991, carbon nanotubes (CNTs) have attracted great attention because of their unique properties. CNTs can be visualized as a sheet of graphite that has been rolled into a tube, and divided into multiwalled carbon nanotubes (MWNTs) [20] and single- 
walled carbon nanotubes (SWNTs) [21] according to the carbon atom layers in the wall of the nanotubes. The hexagonal arrays of carbon atoms in graphene sheets of the CNTs surface have a strong interaction with other molecules or atoms, which make CNTs a promising adsorbent material as a replacement for activated carbon in many applications. Recently, CNTs show high efficiency for $\mathrm{Pb}^{2+}, \mathrm{Cd}^{2+}$ and $\mathrm{F}^{-}$removal from aqueous solution after oxidation treatment with nitric acid [22-24].

In the present work, the analytical potential of MWNTs modified with 1-(2-pyridylazo)-2-naphthol (PAN) as an adsorbent for the preconcentration of traces amounts of the zinc and thallium ions was investigated. This method is described in detail in the experimental section and was applied to measure zinc and thallium ions in water samples.

\section{Experimental}

\subsection{Apparatus and Reagents}

A Varian model SensAA GBC (Dandenong, Australia) atomic absorption spectrometer was used for measuring $\mathrm{Tl}(\mathrm{I})$ and $\mathrm{Zn}(\mathrm{II})$ in air-acetylene flame. A Metrohm $\mathrm{pH}$ meter (Herisau, Switzerland) was employed for $\mathrm{pH}$ measurements. A funnel-tipped glass tube $(80 \times 10 \mathrm{~mm})$ was used as a column for preconcentration. All glass ware and columns were washed with a mixture of concentrated hydrochloric acid and concentrated nitric acid (1:1) before use. Deionized water was used for all dilutions. High purity reagents from Sigma (St. Louis, MO, USA) and Merck (Darmstadt, Germany) were used for all preparations of the standard and sample solutions. Stock solutions of thallium and zinc were prepared by dissolving appropriate amount of ultra pure salt obtained from Merck (Darmstadt, Germany) in $1 \mathrm{~mol} \cdot \mathrm{L}^{-1} \mathrm{HNO}_{3}$. The working solutions were prepared by appropriate dilution of the stock solutions. Multiwalled carbon nanotubes of 95\% purity and length $1-10 \mu \mathrm{m}$, number of walls $3-15$ were purchased from Plasma Chem GmbH (Berlin, Germany). A $0.1 \%$ solution of 1-(2-pyridylazo)-2-naphthol (PAN) in ethanol was prepared. Buffer solution was prepared from $0.2 \mathrm{~mol} \cdot \mathrm{L}^{-1}$ potassium dihydrogen phosphate and disodium hydrogen phosphate for $\mathrm{pH}$ 6. Solutions of alkali metal salts $(1 \%)$ and various metal salts $(0.1 \%)$ were used for studying the interference of anions and cations, respectively.

\subsection{Preparation of Column}

A short glass column with a length of $80 \mathrm{~mm}$ and an inner diameter of $10 \mathrm{~mm}$ plugged with a small portion of cotton at both ends was prepared with fifty milligram of modified MWNTs. Before use, $5 \mathrm{~mL}$ of $2.0 \mathrm{~mol} \cdot \mathrm{L}^{-1} \mathrm{HCl}$ solution and $10 \mathrm{~mL}$ of deionized were passed through the column in order to clean and condition it. Then, the co- lumn was conditioned to the described $\mathrm{pH}$ with $5 \mathrm{~mL}$ of buffer solution.

\subsection{SPE Procedure}

All standards and samples were prepared for analysis according to the following procedure. $20 \mathrm{~mL}$ of each sample was placed in a beaker. To each beaker, $5 \mathrm{~mL}$ of $0.2 \mathrm{~mol} \cdot \mathrm{L}^{-1}$ phosphate buffer $(\mathrm{pH} 6)$ was added. The resulting solution was passed through the column at flow rate of about $1.5 \mathrm{~mL} \cdot \mathrm{min}^{-1}$. Then, the column was rinsed with $5.0 \mathrm{~mL}$ of deionized and the adsorbed ions were eluted with $5.0 \mathrm{~mL}$ of $1.0 \mathrm{~mol} \cdot \mathrm{L}^{-1} \mathrm{HCl}$ at flow rate of 0.8 $\mathrm{mL} \cdot \mathrm{min}^{-1}$. The final solution was aspirated directly into the flame atomic absorption spectrometry for determination of analyte ions.

\section{Results and Discussion}

A large number of studies have been reported on use of MWNTs for metal ion removal from aqueous solution but were not selective. Recent works [25-28] indicates that the MWCNTs can adsorb organic material, so we decided to add PAN to MWCNTs. These modified multiwalled carbon nanotubes have a greater capacity for adsorption and selectivity of ions.

The aim of the described research was to develop a sorbent for simultaneous separation and preconcentration of trace amounts of thallium and zinc. A simple, sensitive, rapid, and economical method was developed for flame atomic absorption spectrometry determination of trace amounts of thallium and zinc ions after separation and preconcentration by modified MWCNTs. Several factors that may affect the preconcentration and extraction process, including $\mathrm{pH}$, type and volume of elution solution, flow rate of sample and eluent, sample volume and matrix effect were optimized.

\subsection{Effect of the Sample pH}

The formation of metal-chelate and its chemical stability are the two important influence factors for SPE. The influence of $\mathrm{pH}$ on the recovery of thallium and zinc ions was examined in the $\mathrm{pH}$ range of $3-9$. The results are shown in Figure 1. The analyte ions were quantitatively recovered in the $\mathrm{pH}$ range of 3.0 - 6.5. At the $\mathrm{pHs}$ higher than $6.5 \mathrm{TlOH}$ and $\mathrm{Zn}(\mathrm{OH})_{2}$ could be formed, therefore extraction efficiency was decreased. In subsequent experiments, the $\mathrm{pH}$ was kept at approximately 6 using potassium dihydrogen phosphate and disodium hydrogen phosphate buffer solution.

\subsection{Effect of Eluent Type, Concentration and Volume}

The selection of an appropriate eluent solvent is one of 


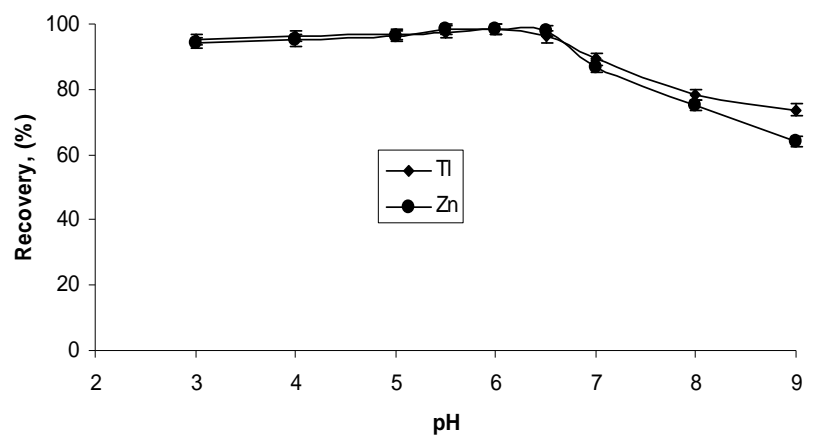

Figure 1. The influence of the $\mathrm{pH}$ of aqueous solution on the recovery of thallium and zinc ions. Conditions: thallium, $25.0 \mu \mathrm{g}$; zinc, $1.0 \mu \mathrm{g}$; flow rate of sample, $1.5 \mathrm{~mL} \cdot \mathrm{min}^{-1}$; flow rate of eluent, $0.8 \mathrm{~mL} \cdot \mathrm{min}^{-1}$; final solution, $5.0 \mathrm{~mL}$ of $1.0 \mathrm{~mol} \cdot \mathrm{L}^{-1} \mathrm{HCl}$ solution; reference, reagent blank.

the important factors to be considered in SPE. The eluent solvent should fulfill the following requirements: 1) the eluent should desorb the metals complexes; 2) the eluent should not destroy the sorbent; and 3) the eluent should be suitable for the subsequent determination technique [29].

Various inorganic and organic solvents $(5.0 \mathrm{~mL})$ were tested to choose the best solution for the elution of the analyte ions accumulated on modified MWCNTs, and the percentage recovery for each eluent type was determined. Organic solvents can be used as eluent but removed the complexing agent from the sorbent. If acid solutions were used as eluent, the reagent was retained on the sorbent and therefore, allowed using the column several times. Among the inorganic solvents studied, acids provided higher recovery efficiency compared to the other inorganic solvents, and the highest recoveries were obtained with $\mathrm{HCl}$. The results are given in Table $\mathbf{1}$.

After this, the experiments were carried out for selecting the concentration of hydrochloric acid solution. Hydrochloric acid solutions at the concentrations of $0.5,1.0$, 1.5, 2.0 and $3.0 \mathrm{~mol} \cdot \mathrm{L}^{-1}$ were studied for this purpose.

Table 1. Effect of type and concentration of eluent on the recovery of the analyte ions.

\begin{tabular}{ccc}
\hline \multirow{2}{*}{ Eluent type and concentration } & \multicolumn{2}{c}{ Recovery (\%) } \\
\cline { 2 - 3 } & $\mathrm{Tl}(\mathrm{I})$ & $\mathrm{Zn}(\mathrm{II})$ \\
\hline $0.5 \mathrm{~mol} \cdot \mathrm{L}^{-1} \mathrm{HNO}_{3}$ & 53 & 59 \\
$1.0 \mathrm{~mol} \cdot \mathrm{L}^{-1} \mathrm{HNO}_{3}$ & 71 & 65 \\
$2.0 \mathrm{~mol} \cdot \mathrm{L}^{-1} \mathrm{HNO}_{3}$ & 82 & 77 \\
$0.5 \mathrm{~mol} \cdot \mathrm{L}^{-1} \mathrm{KSCN}$ & 43 & 59 \\
$0.5 \mathrm{~mol} \cdot \mathrm{L}^{-1} \mathrm{Na}_{2} \mathrm{~S}_{2} \mathrm{O}_{3}$ & 36 & 51 \\
$0.5 \mathrm{~mol} \cdot \mathrm{L}^{-1} \mathrm{HCl}$ & 72 & 82 \\
$1.0 \mathrm{~mol} \cdot \mathrm{L}^{-1} \mathrm{HCl}$ & 97 & 98 \\
$1.5 \mathrm{~mol} \cdot \mathrm{L}^{-1} \mathrm{HCl}$ & 98 & 97 \\
$2 \mathrm{~mol} \cdot \mathrm{L}^{-1} \mathrm{HCl}$ & 99 & 98 \\
$3 \mathrm{~mol} \cdot \mathrm{L}^{-1} \mathrm{HCl}$ & 98 & 98 \\
\hline
\end{tabular}

The results are given in Table 1. The results showed that the extraction efficiency increased with increasing concentration of hydrochloric acid solution up to $1.0 \mathrm{~mol} \cdot \mathrm{L}^{-1}$ and further concentration of hydrochloric acid solution has no effect on the recovery percent. Therefore, $\mathrm{HCl} 1.0$ $\mathrm{mol} \cdot \mathrm{L}^{-1}$ solution was selected for further experiments.

For further enhancing the sensitivity and the preconcentration factor of the method low volume of eluent was used. For this purpose, the effect of eluent volume on the desorption of the analytes ions at a concentration of 1.0 $\mathrm{mol} \cdot \mathrm{L}^{-1}$ has been studied by keeping eluent concentration of $1.0 \mathrm{~mol} \cdot \mathrm{L}^{-1}$ and varying its volumes from 1.0 to 10.0 $\mathrm{mL}$. The experimental results indicated that with $5.0 \mathrm{~mL}$ $\mathrm{HCl} 1.0 \mathrm{~mol} \cdot \mathrm{L}^{-1}$, quantitative recoveries $(>97 \%)$ for the analyte ions could be obtained. Therefore, $5.0 \mathrm{~mL}$ of eluent volume was selected for subsequent experiments.

\subsection{Effect of Sample Flow Rate}

It is obvious that the flow rate of sample is an important parameter that controls the time of analysis and affects the retention of analyte ions on the sorbent. While the recovery increases with the decreasing flow rate, the preconcentration time increases. To obtain the quantitative recovery and to decrease the preconcentration time, the sample flow rate was investigated in the range $1-3 \mathrm{~mL}$ $\min \cdot \mathrm{L}^{-1}$. The results were shown that retention of the analyte ions were independent of flow rate in a range of $1-2$ $\mathrm{mL} \cdot \mathrm{min}^{-1}$. Therefore a flow rate of $1.5 \mathrm{~mL} \cdot \mathrm{min}^{-1}$ was chosen for sample solutions in all subsequent experiments.

\subsection{Effect of Eluent Flow Rate}

The flow rate of eluent solution affects the recoveries of the analyte ions and duration of complete analysis. Therefore, the effect of the flow rates of eluent solutions were examined under the optimum conditions $(\mathrm{pH}$ and eluent type). The results were shown that desorption of the analyte ions were independent of flow rate in the range of 0.5 $-1.0 \mathrm{~mL} \cdot \mathrm{min}^{-1}$. Therefore a flow rate of $0.8 \mathrm{~mL} \cdot \mathrm{min}^{-1}$ was chosen for eluent solutions in all subsequent experiments.

\subsection{Breakthrough Volume}

The breakthrough volume is an important parameter in SPE because breakthrough volume represents the sample volume that can be preconcentrated without loss of analyte during elution of the sample [30]. The breakthrough volume of the sample solution was studied by dissolving $5.0 \mu \mathrm{g}$ of thallium and $1.0 \mu \mathrm{g}$ of zinc ions in different volumes $(25-800 \mathrm{~mL})$ and the SPE procedure was followed. The results were shown that, $\mathrm{Tl}(\mathrm{I})$ and $\mathrm{Zn}(\mathrm{II})$ ions were recovered quantitatively in the volume range of 25 700. Therefore, preconcentration factor (the ratio of the highest sample volume for both the analytes $(700 \mathrm{~mL})$ and the lowest eluent volume $(5.0 \mathrm{~mL}))$ was 140 . 


\subsection{Adsorption Capacity}

The adsorption capacity is the maximum metal quantity taken up by $1 \mathrm{~g}$ of modified sorbent and given by $\mathrm{mg} \cdot \mathrm{g}^{-1}$. To determine adsorption capacity of the modified MWNTs, a batch method was selected. $50 \mathrm{~mL}$ of aqueous solution containing $2.0 \mathrm{mg}$ of thallium and $0.80 \mathrm{mg}$ zinc at $\mathrm{pH} 6$ was added to $0.1 \mathrm{~g}$ of modified MWNTs. After shaking for $10 \mathrm{~min}$, the mixture was filtered and $10 \mathrm{~mL}$ of supernatant solution was diluted to $100.0 \mathrm{~mL}$ and was determined by FAAS. This procedure was repeated for each analyte ions separately. The capacity of modified MWNTs for thallium and zinc ions was found to be 8.8 and 6.4 $\mathrm{mg} \cdot \mathrm{g}^{-1}$, respectively.

\subsection{Effect of Potentially Interfering Ions}

In view of the high selectivity provided by flame atomic absorption spectrometry, the only interference may be attributed to the extraction step. Natural water samples contain commonly alkali, alkaline earth and some transition element salts. Therefore, the effects of some anions and cations at various concentrations on the recovery of the analyte ions were studied. For this purpose, an aliquot of aqueous solution $(25 \mathrm{~mL})$ containing $25.0 \mu \mathrm{g}$ of thallium and $1.0 \mu \mathrm{g}$ of zinc ions was taken with different amounts of foreign ions and the SPE procedure was followed. The tolerance limit was defined as the highest amount of foreign ions that produced an error no greater than $\pm 5 \%$ in the determination of the analyte ions. The results are given in Table 2 . The results demonstrate that the presence of large amounts of species commonly present in water samples have no significant effect on the determination of analyte ions.

Table 2. Tolerance limit of foreign ions.

\begin{tabular}{cccc}
\hline & & \multicolumn{2}{c}{$\begin{array}{c}\text { Interference/Analyte } \\
\text { ions(II) ratio }\end{array}$} \\
\cline { 3 - 4 } Foreign ions & Added as & $\mathrm{Tl}(\mathrm{I})$ & $\mathrm{Zn}(\mathrm{II})$ \\
\hline $\mathrm{CH}_{3} \mathrm{COO}^{-}$ & $\mathrm{CH}_{3} \mathrm{COONa}, 3 \mathrm{H}_{2} \mathrm{O}$ & $>5000$ & $>5000$ \\
$\mathrm{NH}_{4}^{+}$ & $\mathrm{NH}_{4} \mathrm{Cl}$ & $>5000$ & $>5000$ \\
$\mathrm{H}_{2} \mathrm{PO}_{4}^{-}$ & $\mathrm{KH}_{2} \mathrm{PO}_{4}$ & $>5000$ & $>5000$ \\
$\mathrm{HPO}_{4}^{2-}$ & $\mathrm{Na}_{2} \mathrm{HPO}_{4}$ & $>5000$ & $>5000$ \\
$\mathrm{Ca}^{2+}, \mathrm{Mg}^{2+}$ & $\mathrm{CaCl}_{2}, \mathrm{MgCl}_{2}$ & 2000 & 2000 \\
$\mathrm{Al}^{3+}$ & $\mathrm{AlCl}_{3}$ & 100 & 100 \\
$\mathrm{As}^{3+}$ & $\mathrm{AsCl}_{3}$ & 500 & 1000 \\
$\mathrm{Cu}^{2+}$ & $\left.\mathrm{Cu}^{2+} \mathrm{NO}_{3}\right)_{2}$ & 250 & 200 \\
$\mathrm{Ba}^{2+}$ & $\mathrm{BaCl}_{2}$ & 150 & 200 \\
$\mathrm{Fe}^{3+}$ & $\mathrm{Fe}^{2+}\left(\mathrm{NO}_{3}\right)_{3}$ & 100 & 150 \\
$\mathrm{Mn}^{2+}$ & $\mathrm{MnSO}_{4}$ & 300 & 1000 \\
$\mathrm{Co}^{2+}$ & $\mathrm{Co}^{2+}\left(\mathrm{NO}_{3}\right)_{2}$ & 150 & 200 \\
\hline & & &
\end{tabular}

\subsection{Analytical Figures of Merite}

Figures of merit of the method were obtained by processing standard solution of the analyte ions. Under the optimized conditions, calibration curves were constructed for the determination of thallium and zinc according to SPE procedure. Linearity was maintained between 0.1 to 20.0 $\mu \mathrm{g} \cdot \mathrm{mL}^{-1}$ for thallium and $20.0 \mathrm{ng} \cdot \mathrm{mL}^{-1}$ to $0.5 \mu \mathrm{g} \cdot \mathrm{mL}^{-1}$ for zinc in the final solution. The detection limits based on three times the standard deviation of the blank signal $(\mathrm{n}=$ 8) for thallium and zinc were $5.1 \mathrm{ng} \cdot \mathrm{mL}^{-1}$ and $1.4 \mathrm{ng} \cdot \mathrm{mL}^{-1}$, respectively. Seven replicate determination of a mixture of $5.0 \mu \mathrm{g} \cdot \mathrm{mL}^{-1}$ thallium and $0.2 \mu \mathrm{g} \cdot \mathrm{mL}^{-1}$ zinc in the final solution gave a mean absorbance of 0.085 and 0.074 with relative standard deviation $1.5 \%$ and $1.7 \%$, respectively. The analytical parameters are given in Table 3.

\subsection{Accuracy Check of the SPE Procedure}

The accuracy of the SPE procedure was applied to the determination of thallium and zinc ions in National Institute for Environment Studies (NIES) No. 1 pepperbush and NIES No. 3 Chlorella. Approximately $0.01 \mathrm{~g}$ of NIES No. 1 and No. 3 were weighed accurately into a Teflon cup and dissolved in concentrated nitric acid $(\sim 10 \mathrm{~mL})$ with heating on a water bath. The solution was cooled, diluted and filtered. The filtrate was made to $100.0 \mathrm{~mL}$ with deionized water in a calibrated flask. An aliquot of the sample solution was taken and thallium and zinc ions were determined by the SPE procedure. The results are given in Table 4, are in good agreement with the certified value.

Table 3. Analytical parameters of the method.

\begin{tabular}{cc}
\hline Statistical parameters & Element \\
\hline Linear ranges $\left(\mu \mathrm{g} \cdot \mathrm{mL}^{-1}\right)$ & $\mathrm{Tl}: 0.1-20.0$ \\
& $\mathrm{Zn}: 0.02-0.5$ \\
Regression equations & $\mathrm{A}_{\mathrm{Tl}}=0.0178 \mathrm{X}+0.0007$ \\
$\mathrm{~A}_{\mathrm{Zn}}=0.3822 \mathrm{X}+0.0041$ \\
Correlation coefficients $(\mathrm{R})$ & $\mathrm{Tl}: 0.9994$ \\
& $\mathrm{Zn}: 0.9967$ \\
$\mathrm{RSD} \%$ & $\mathrm{Tl}: 1.5$ \\
& $\mathrm{Zn}: 1.7$ \\
Detection limits $\left(\mathrm{ng} \cdot \mathrm{mL}^{-1}\right)$ & $\mathrm{Tl}: 5.1$ \\
& $\mathrm{Zn}: 1.4$ \\
\hline
\end{tabular}

Table 4. Determination of $\mathrm{Tl}(\mathrm{I})$ and $\mathrm{Zn}(\mathrm{II})$ ions in certified reference materials.

\begin{tabular}{ccc}
\hline Sample & Certified Value $\left(\mu \mathrm{g} \cdot \mathrm{g}^{-1}\right)^{\mathrm{b}}$ & Found $^{\mathrm{a}}\left(\mu \mathrm{g} \cdot \mathrm{g}^{-1}\right)$ \\
\hline NIES, No. 1 & Zn, $340 \pm 20$ & Zn: $341.7 \pm 11.3$ \\
Pepperbush & & Tl: $50.5 \pm 2.5$ \\
NIES, No. 3 & Zn, 20.5 \pm 1.0 & Zn: $20.2 \pm 0.9$ \\
Chlorella & & Tl: $49.2 \pm 2.1$ \\
\hline
\end{tabular}

${ }^{\mathrm{a}}$ Average of four determination \pm standard deviation; ${ }^{\mathrm{b}} 50.0 \mu \mathrm{g}$ thallium was added. 
Table 5. Determination of $\mathrm{Tl}(\mathrm{I})$ and $\mathrm{Zn}(\mathrm{II})$ ions in water samples.

\begin{tabular}{|c|c|c|c|c|}
\hline Sample & $\begin{array}{c}\text { Found }^{\mathrm{a}} \\
\left(\mathrm{ng} \cdot \mathrm{mL}^{-1}\right)\end{array}$ & $\begin{array}{c}\text { Added } \\
\left(\mathrm{ng} \cdot \mathrm{mL}^{-1}\right)\end{array}$ & $\begin{array}{c}\text { Found } \\
\left(\mathrm{ng} \cdot \mathrm{mL}^{-1}\right)\end{array}$ & $\operatorname{Re}(\%)$ \\
\hline $\begin{array}{l}\text { River Water } \\
\text { (Rayen, } \\
\text { Kerman) }\end{array}$ & $\begin{array}{c}\text { Tl: N.D. }{ }^{b} \\
\text { Zn: } 20.9 \pm 0.7\end{array}$ & $\begin{array}{l}\text { Tl: } 50.0 \\
\mathrm{Zn}: 10.0\end{array}$ & $\begin{array}{l}\text { Tl: } 50.8 \pm 2.4 \\
\text { Zn: } 31.2 \pm 1.2\end{array}$ & $\begin{array}{c}101.6 \\
103\end{array}$ \\
\hline $\begin{array}{l}\text { River Water } \\
\text { (Shahdad, } \\
\text { Kerman) }\end{array}$ & $\begin{array}{c}\text { Tl: N.D. } \\
\text { Zn: } 24.9 \pm 0.8\end{array}$ & $\begin{array}{l}\text { Tl: } 50.0 \\
\text { Zn: } 10.0\end{array}$ & $\begin{array}{l}\text { Tl: } 51.9 \pm 2.6 \\
\text { Zn: } 34.7 \pm 1.3\end{array}$ & $\begin{array}{c}103.8 \\
98\end{array}$ \\
\hline $\begin{array}{l}\text { River Water } \\
\text { (Kohpayeh, } \\
\text { Kerman) }\end{array}$ & $\begin{array}{c}\text { Tl: N.D. } \\
\text { Zn: } 23.0 \pm 0.7\end{array}$ & $\begin{array}{l}\text { Tl: } 50.0 \\
\text { Zn: } 10.0\end{array}$ & $\begin{array}{c}\mathrm{Tl}: 50.5 \pm 0.4 \\
\mathrm{Zn}: 33.2 \pm 1.3\end{array}$ & $\begin{array}{l}101 \\
102\end{array}$ \\
\hline
\end{tabular}

${ }^{a}$ Average of four determination, \pm standard deviation; ${ }^{b}$ Not detect.

Table 6. Comparison the detection limits of proposed methods with other methods.

\begin{tabular}{|c|c|c|c|}
\hline Method & $\begin{array}{l}\text { Enrichment } \\
\text { factor }\end{array}$ & $\begin{array}{l}\text { Detection limit } \\
\left(\mathrm{ng} \cdot \mathrm{mL}^{-1}\right)\end{array}$ & Ref. \\
\hline SPE-FAAS & Zn: 63 & Zn: 1.6 & [31] \\
\hline SPE-FAAS & Zn: 292 & Zn: 0.69 & [32] \\
\hline $\begin{array}{l}\text { Thermospray flame furnace } \\
\text { atomic absorption } \\
\text { spectrometry }\end{array}$ & - & Zn: 0.9 & [33] \\
\hline SPE-FAAS & Zn: 90 & $\mathrm{Zn}: 1.23$ & [34] \\
\hline SPE-FAAS & Zn: 17.6 & Zn: 0.8 & [35] \\
\hline SPE-FAAS & Tl: 77 & $\mathrm{Tl}: 2.5$ & [36] \\
\hline Optical chemical sensor & - & Tl: 224.8 & [37] \\
\hline Anodic stripping voltametry & - & Tl: 10 & [38] \\
\hline $\begin{array}{l}\text { Electrothermal } \\
\text { vaporization-ICP-MS }\end{array}$ & - & Tl: 3 & [39] \\
\hline SPE-FAAS & 140 & $\begin{array}{l}\text { Tl: } 5.1 \\
\text { Zn: } 1.4\end{array}$ & $\begin{array}{l}\text { This } \\
\text { work }\end{array}$ \\
\hline
\end{tabular}

\subsection{Applicability of SPE Procedure for Analysis of Water Samples}

River water samples were collected in acid-leached polyethylene bottles. The river water samples were collected from Rayen, Shahdad and Kohpayeh in Kerman Province, Iran. The only pretreatment was acidification to $\mathrm{pH} 2$ with nitric acid, which was performed immediately after collection, in order to prevent adsorption of the metal ions on the flask walls. The samples were filtered before analyses through a cellulose membrane (Millipore) of $0.45 \mu \mathrm{m}$ pore size.

The SPE procedure has been applied to the determination of thallium and zinc ions in different water samples. Also, the recovery of thallium and zinc ions from water samples spiked with $\mathrm{Tl}(\mathrm{I})$ and $\mathrm{Zn}$ (II) ions were studied. The results are given in Table 5.

The results were shown that, the added ions can be quantitatively recovered from the water samples by the SPE procedure. These results demonstrate the applica- bility of the SPE procedure for thallium and zinc ions determination in water samples.

\section{Conclusion}

The present study demonstrates preparation and use of a sorbent based on the modification of MWCNTs with PAN reagent. The modification of MWCNTs is simple, and the reagent remains in the column, which allows it to be used several times. It can be concluded from the results that modified MWNTs is an effective sorbent for trace amounts of thallium and zinc ions and can be used for its preconcentration from various samples. The proposed method has the following advantages: simple, rapid, high enrichment factor (140), reproducible, accurate and low analysis cost. Instead of the use of fresh solvent as an extracting phase for each sample, the reusability of adsorbent was as high as greater than $30 \mathrm{cy}-$ cles without any loss in its sorption behavior. A comparison of the proposed method with the other reported preconcentration methods [31-39] for zinc and thallium extraction from water samples are given in Table 6. The obtained detection limits by the proposed method are comparable to most of those reported in the literature.

\section{REFERENCES}

[1] L. Willis, P. Thureen, J. Kaufman, E. Wymore, H. Skillman and E. da Cruz, "Removal of Copper Ions from Aqueous Solutions by Kaolinite and Batch Design," Journal of Hazardous Material, Vol. 153, No. 1-2, 2008, pp. 867-876. doi:10.1016/j.jhazmat.2007.09.047

[2] T. Kocaoba and T. Akyuz, "Effects of Conditioning of Sepiolite Prior to Cobalt and Nickel Removal," Desalination, Vol. 181, No. 1-3, 2005, pp. 313-318. doi:10.1016/j.desal.2005.04.010

[3] B. Rezaei, E. Sadeghi and S. Meghdadi, "Nano-Level Determination of Copper with Atomic Absorption Spectrometry after Pre-Concentration on N,N-(4-Methyl-1,2Phenylene)diquinoline-2-carboxamide-naphthalene," Journal of Hazardous Material, Vol. 168, No. 2-3, 2009, pp. 787-792. doi:10.1016/j.jhazmat.2009.02.077

[4] T. Madrakian, M. A. Zolfigol and M. Solgi, "Solid-Phase Extraction Method for Preconcentration of Trace Amounts of Some Metal Ions in Environmental Samples Using Silica Gel Modified by 2,4,6-Trimorpholino-1,3,5-Triazin," Journal of Hazardous Material, Vol. 160, No. 2-3, 2008, pp. 468-472. doi:10.1016/j.jhazmat.2008.03.021

[5] A. Tobiasz, S. Walas, B. Trzewik, P. Grzybek, M. M. Zaitz, M., Gawin and H. Mrowiec, "Cu(II)-Imprinted Styrene-Divinylbenzene Beads as a New Sorbent for Flow Injection-Flame Atomic Absorption Determination of Copper," Microchemical Journal, Vol. 93, No. 1, 2009, pp. 87-92. doi:10.1016/j.microc.2009.05.002

[6] M. Burguera and J. L. Burguera, "On-Line Electrothermal Atomic Absorption Spectrometry Configurations: Recent Developments and Trends," Spectrochimica Acta Part B: 
Atomic Spectroscopy, Vol. 62, No. 9, 2007, pp.884-896. doi:10.1016/j.sab.2006.12.011

[7] A. Sabarudin, N. Lenghor, M. Oshima, L. Hakini, T. Takayanagi, Y. H. Gao and S. Motomizua, "On-Line Electrothermal Atomic Absorption Spectrometry Configurations: Recent Developments and Trends," Talanta, Vol. 72, No. 5, 2007, pp. 1609-1617. doi:10.1016/j.talanta.2007.01.024

[8] A. Ramesh, K. R. Mohan and K. Sshaiah, "On-Line Electrothermal Atomic Absorption Spectrometry Configurations: Recent Developments and Trends," Talanta, Vol. 57, No. 2, 2002, pp. 243-252. doi:10.1016/S0039-9140(02)00033-4

[9] A. Duran, T. Tuzen and M. Soylak, "Preconcentration of Some Trace Elements via Using Multiwalled Carbon Nanotubes as Solid Phase Extraction Adsorbent," Journal of Hazardous Material, Vol. 169, No. 1-3, 2009, pp. 466-471. doi:10.1016/i.jhazmat.2009.03.119

[10] Z. K. Wang, et al., "Vaporization and Ionization of Laser Ablation Generated Aerosols in an Inductively Coupled Plasma Mass Spectrometer-Implications from Ion Distribution Maps," Journal of Analytical Atomic Spec- trometry, Vol. 21, 2006, pp. 1143-1151. doi:10.1039/b607469n

[11] M. Soylak and M. Tuzen, "Coprecipitation of Gold(III), Palladium(II) and Lead(II) for Their Flame Atomic Absorption Spectrometric Determinations," Journal of Hazardous Material, Vol. 152, No. 2, 2008, pp. 656-661. doi:10.1016/j.jhazmat.2007.07.027

[12] A. N. Anthemidis, D. G. Themelis and J. A. Stratis, "Stopped-Flow Injection Liquid-Liquid Extraction Spectrophotometric Determination of Palladium in Airborne Particulate Matter and Automobile Catalysts," Talanta, Vol. 54, No. 1, 2001, pp. 37-43. doi:10.1016/S0039-9140(00)00620-2

[13] L. Pan, Y. R. Qin, B. Hu and Z. C. Jiang, "Determination of Nickel and Palladium in Environmental Samples by Low Temperature ETV-ICP-OES Coupled with LiquidLiquid Extraction with Dimethylglyoxime as Both Extractant and Chemical Modifier," Chemical Research of Chinese University, Vol. 23, No. 4, 2007, pp. 399-403. doi:10.1016/S1005-9040(07)60086-5

[14] S. Z. Mohammadi, D. Afzali and D. Pourtalebi, "Flame Atomic Absorption Spectrometric Determination of Trace Amounts of Palladium, Gold and Nickel after Cloud Point Extraction1," Journal of Analytical Chemistry, Vol. 66, No. 7, 2011, pp. 620-625. doi:10.1134/S1061934811070094

[15] D. Afzali, M. A. Taher, A. Mostafavi and S. Z. Mohammadi Mobarakeh, "Thermal Modified Kaolinite as Useful Material for Separation and Preconcentration of Trace Amounts of Manganese Ions," Talanta, Vol. 65, No. 2, 2005, pp. 476-480. doi:10.1016/j.talanta.2004.06.027

[16] M. A.Taher, B. K. Puri and R. K. Bansal, "Simultaneous Determination of Cadmium and Lead in Real and Environmental Samples by Differential Pulse Polarography after Adsorption of Their 2-Nitroso-1-naphthol-4-sulfonic acid-Tetradecyldimethylbenzylammonium Ion-Associated Complex on Microcrystalline Naphthalene," Microchemi- cal Journal, Vol. 58, No. 1, 1998, pp. 21-30. doi:10.1006/mchj.1997.1502

[17] A. Shokrollalii, M. Ghaedi, O. Hossaini, N. Khanjari and M. Soylak, "Cloud Point Extraction and Flame Atomic Absorption Spectrometry Combination for Copper(II) Ion in Environmental and Biological Samples," Journal of Hazardous Material, Vol. 160, No. 2-3, 2008, pp. 435440. doi:10.1016/i.jhazmat.2008.03.016

[18] S. Candir, I. Narin, and M. Soylak, "Ligandless Cloud Point Extraction of $\mathrm{Cr}(\mathrm{III}), \mathrm{Pb}(\mathrm{II}), \mathrm{Cu}(\mathrm{II}), \mathrm{Ni}(\mathrm{II}), \mathrm{Bi}(\mathrm{III})$ and Cd(II) Ions in Environmental Samples with tween 80 and Flame Atomic Absorption Spectrometric Determination," Talanta, Vol. 77, No. 1, 2008, pp. 289-293. doi:10.1016/j.talanta.2008.06.024

[19] L. Elci, A. A. Kartal and M. Soylak, "Solid Phase Extraction Method for the Determination of Iron, Lead and Chromium by Atomic Absorption Spectrometry Using Amberite XAD-2000 Column in Various Water Samples," Journal of Hazardous Material, Vol. 153, No. 1-2, 2008, pp. 454-461. doi:10.1016/i.jhazmat.2007.08.075

[20] S. Iijima, "Helical Microtubules of Graphitic Carbon," Nature, Vol. 354, No. 6348, 1991, pp. 56-58. doi: $10.1038 / 354056 \mathrm{a} 0$

[21] S. Iijima and T. Ichihashi, "Single-Shell Carbon Nanotubes of 1-nm Diameter," Nature, Vol. 363, No. 6430, 1993, pp. 603-605. doi:10.1038/363603a0

[22] Y. Li, S. Wang, A. Cao, D. Zhao, X. Zhang, C. Xu, Z. Luan, D. Ruan, J. Liang, D. Wu and B. Wei, "Adsorption of Fluoride from Water by Amorphous Alumina Supported on Carbon Nanotubes," Chemical Physical Letters, Vol. 350, No. 5-6, 2001, pp. 412-416. doi:10.1016/S0009-2614(01)01351-3

[23] Y. Li, S. Wang, J. Wa, X. Zhang, C. Xu, Z. Luan and D. $\mathrm{Wu}$, "Lead Adsorption on Carbon Nanotubes," Chemical Physical Letters, Vol. 357, No. 3-4, 2002, pp. 263-266. doi:10.1016/S0009-2614(02)00502-X

[24] Y. Li, S. Wang, Z. Luan, J. Ding, C. Xu and D. Wu, "Adsorption of Cadmium(II) from Aqueous Solution by Surface Oxidized Carbon Nanotubes," Carbon, Vol. 41, No. 5, 2003, pp. 1057-1062. doi:10.1016/S0008-6223(02)00440-2

[25] D. Afzali and A. Mostafavi, "Potential of Modified Multiwalled Carbon Nanotubes with 1-(2-Pyridylazo)-2naphtol as a New Solid Sorbent for the Preconcentration of Trace Amounts of Cobalt(II) Ion," Analytical Science, Vol. 24, No. 9, 2008, pp. 1135-1139. doi:10.2116/analsci.24.1135

[26] D. Du, M. Wang, J. Zhang, J. Cai, H. Tu and A. Zhang, "Application of Multiwalled Carbon Nanotubes for SolidPhase Extraction of Organophosphate Pesticide," Electrochemical Communication, Vol. 10, No. 1, 2008, pp. 85-89. doi:10.1016/j.elecom.2007.11.005

[27] G. Z. Fang, J. X. He and S. Wang, "Multiwalled Carbon Nanotubes as Sorbent for On-Line Coupling of SolidPhase Extraction to High-Performance Liquid Chromatography for Simultaneous Determination of 10 Sulfonamides in Eggs and Pork," Journal of Chromatography A, Vol. 1127, No. 1-2, 2006, pp. 12-17. doi:10.1016/j.chroma.2006.06.024 
[28] J. Xu, Y. Wang, Y. Xian, L. Jin and K. Tanaka, "Preparation of Multiwall Carbon Nanotubes Film Modified Electrode and Its Application to Simultaneous Determination of Oxidizable Amino Acids in Ion Chromatography," Talanta, Vol. 60, No. 6, 2003, pp. 1123-1130. doi:10.1016/S0039-9140(03)00214-5

[29] N. J. K. Simpson, "Solid Phase Extraction: Principles, Techniques and Applications," Marcel Decker, New York, 2000. doi:10.1201/9781420056242

[30] Z. Mester and R. Sturgeon, "Sample Preparation for Trace Element Analysis," Elsevier, Amsterdam, 2003.

[31] M. Ghaedi, H. Tavallali, A. Shokrollahi, M. Zahedi, M. Montazerozohori and M. Soylak, "Flame Atomic Absorption Spectrometric Determination of Zinc, Nickel, Iron and Lead in Different Matrixes after Solid Phase Extraction on Sodium Dodecyl Sulfate (SDS)-Coated Alumina as Their Bis (2-Hydroxyacetophenone)-1, 3-Propanedimine Chelates," Journal of Hazardous Material, Vol. 166, No. 2-3, 2009, pp. 1441-1448. doi:10.1016/j.jhazmat.2008.12.066

[32] M. Ghaedi, K. Niknam, A. Shokrollahi, B. Niknath, H. R. Rajabi and M. Soylak, "Flame Atomic Absorption Spectrometric Determination of Trace Amounts of Heavy Metal Ions after Solid Phase Extraction Using Modified Sodium Dodecyl Sulfate Coated on Alumina," Journal of Hazardous Material, Vol. 155, No. 1-2, 2008, pp. 121127. doi:10.1016/j.jhazmat.2007.11.038

[33] C. C. Nascentes, M. Y. Kamogawa, K. G. Fernandes, M. A. Z. Arruda, A. R. A. Nogueira and L. A. Nobreg, "Direct Determination of $\mathrm{Cu}, \mathrm{Mn}, \mathrm{Pb}$, and $\mathrm{Zn}$ in Beer by Thermospray Flame Furnace Atomic Absorption Spectrometry," Spectrochimica Acta Part B: Atomic Spectroscopy, Vol. 60, No. 5, 2005, pp. 749-753. doi:10.1016/j.sab.2005.02.012

[34] M. Ghaedi, K. Niknam, A. Shokrollahi, E. Niknam, H. Ghaedi and M. Soylak, "A Solid Phase Extraction Procedure for $\mathrm{Fe}^{3+}, \mathrm{Cu}^{2+}$ and $\mathrm{Zn}^{2+}$ Ions on 2-phenyl-1H- benzo $[d]$ Imidazole Loaded on Triton X-100-Coated Polyvinyl Chloride," Journal of Hazardous Material, Vol. 158, No. 1, 2008, pp. 131-136. doi:10.1016/j.jhazmat.2008.01.037

[35] J. S. Carletto, K. C. Di Pietro Roux, H. F. Maltez, E. Martendal and E. Carasek, "Use of 8-Hydroxyquinolinechitosan Chelating Resin in an Automated On-Line Preconcentration System for Determination of Zinc(II) by F AAS," Journal of Hazardous Material, Vol. 157, No. 1, 2008, pp. 88-93. doi:10.1016/j.jhazmat.2007.12.083

[36] S. Dadfarnia, T. Assadolkhi and A. M. Haji Shabani, "Speciation and Determination of Thallium by On-Line Microcolumn Separation/Preconcentration by Flow Injection-Flame Atomic Absorption Spectrometry Using Immobilized Oxine as Sorbent," Journal of Hazardous Material, Vol. 148, No. 1-2, 2007, pp. 446-452. doi:10.1016/j.jhazmat.2007.02.059

[37] M. Fouladgar and A. A. Ensafi, "A Novel Optical Chemical Sensor for Thallium(III) Determination Using 4-(5Bromo-2-pyridylazo)-5-(diethylamino)-phenol," Sensor and Actuators B: Chemical, Vol. 143, No. 2, 2010, pp. 590594. doi:10.1016/j.snb.2009.09.057

[38] N. Spano, A. Panzanelli, P. P. Costantina, M. I. Pilo, G. Sanna, R. Seeber and A. Tapparo, "Anodic Stripping Voltammetric Determination of Traces and Ultratraces of Thallium at a Graphite Microelectrode: Method Development and Application to Environmental Waters", Analytica Chimica Acta, Vol. 553, No. 1-2, pp. 201-207. doi:10.1016/j.aca.2005.08.003

[39] S. M. Maia, M. G. R. Vale, B. Welz and A. J. Curtius, "Feasibility of Isotope Dilution Calibration for the Determination of Thallium in Sediment Using Slurry Sampling Electrothermal Vaporization Inductively Coupled Plasma Mass Spectrometry," Spectrochimica Acta Part B, Vol. 56, No. 7, 2001, pp. 1263-1275. doi:10.1016/S0584-8547(01)00206-3 